\title{
The Acquisitions of the Chinese State-Owned Enterprises under the National Merger Control Regimes of the EU Member States: Searching for a Coherent Approach*
}

\author{
Alexandr Svetlicinii**
}

\begin{abstract}
With the rapidly unfolding China's Belt and Road Initiative (BRI) and the ongoing reform of the State-owned enterprises (SOEs), the number of overseas acquisitions by the Chinese SOEs in various industrial and services sectors is gradually on the rise. These transactions have raised a number of questions in terms of the assessment of the economic concentrations' potential impact on competition and challenged the traditional assessment tools employed by the merger control regimes. The paper examines the evolving experience of Chinese SOEs' acquisitions in the European Union (EU), which are subject to ex ante assessment under both $\mathrm{EU}$ and national merger control regimes. The analysis of the merger assessment practice of the EU Commission culminating in the recent conditional approval of the ChemChina/Syngenta merger indicates that the traditional assessment tools, when applied to the acquisitions by Chinese SOEs, may no longer be adequate to grasp the essence of their corporate governance and decision-making. The review of the merger control practice of the national competition authorities (NCAs) also demonstrates the absence of a coherent assessment approach to the cases involving Chinese SOEs, which may lead to the inconsistent enforcement and strengthening of the foreign investment screening on grounds other than market competition.
\end{abstract}

KEYWORDS: State-owned enterprise, Belt and Road Initiative, merger control, national competition authority, competition law

\footnotetext{
* Date of Reception: 29 December 2017. Date of Acceptance: 30 January 2018.

** LL.M (CEU), MRes (EUI), PhD (EUI); Assistant Professor at the University of Macau, Faculty of Law; 999078 Macao SAR (China); alexandrs@umac.mo. The author presented working drafts of the paper at the European Union Academic Programme Macao Biannual Conference "60 Years after the Treaties of Rome: What is the Future for the European Union?" in Macao on 27 November 2017, and at the Asian Competition Forum $13^{\text {th }}$ Annual Conference "Asian Regional Competition Issues: Corruption, Communications, Nationalism: Globalisation in Reverse?” in Hong Kong on 11 December 2017.
} 


\section{Introduction}

The Belt and Road Initiative (BRI) officially unveiled in $2013^{1}$ and labelled by the commentators as "globalization with Chinese characteristics"2 provided for USD 900 billion worth of planned investments in infrastructure across Central and South Asia, the Middle East, and Central and Eastern Europe (CEE). ${ }^{3}$ The pursuit of the BRI objectives was embedded into the Constitution of the Chinese Communist Party (CCP), revised at the $19^{\text {th }}$ National Congress of the CCP in October 2017. ${ }^{4}$ The Action Plan on BRI released in 2015 calls for the improvement of the investment, trade facilitation and removal of the recurrent investment and trade barriers. ${ }^{5}$

The leading role in the BRI is expected to be played by the State-owned enterprises (SOEs). ${ }^{6}$ In the words of the Chinese Premier Li Keqiang, "Chinese SOE's participation in global cooperation on production capacity, especially through the newly introduced Silk Road Economic Belt and the $21^{\text {st }}$ Century Maritime Silk Road, will benefit not only the Chinese economy but also other economies". The Guiding Opinions of the State Council on outbound investment highlighted the following types of outbound investment by Chinese enterprises, which are encouraged and

\footnotetext{
${ }^{1}$ See Ministry of Foreign Affairs of the People's Republic of China, "President Xi Jinping delivers important speech and proposes to build a silk road economic belt with Central Asian countries", 7 September 2013, http://www.fmprc.gov.cn/mfa_eng/topics_665678/xjpfwzysiesgjtthshzzfh_665686/t1076334.shtml.

${ }^{2}$ See e.g. Jason Zukus, "Globalization with Chinese characteristics: A new international standard?”, The Diplomat, 9 May 2017, https://thediplomat.com/2017/05/globalization-with-chinesecharacteristics-a-new-international-standard/.

${ }^{3}$ See The Hague Centre for Strategic Studies, "A road to riches or a road to ruin? The geo-economic implications of China's new silk road", 15 August 2017, https:/hcss.nl/sites/default/files/files/ reports/Geoeconomics_Behind_OBOR_FINAL\%20\%283\%29.pdf, 3. The financial support for the BRI projects will be provided by the Asian Infrastructure Development Bank (with USD 100 billion in authorised capital), the New Development (BRICS) Bank, the New Silk Road Fund (with USD 40 billion capital), Investment Cooperation Fund between China and Central and Eastern European countries (USD 3 billion), etc.

${ }^{4}$ Constitution of the Communist Party of China (revised and adopted at the $19^{\text {th }}$ National Congress of the Communist Party of China on 24 October 2017), http://news.xinhuanet.com/english/download/Constitution_of_the_Communist_Party_of_China.pdf.

${ }^{5}$ State Council of the People's Republic of China, "Full text: Action plan on the Belt and Road Initiative", 30 March 2015, http://english.gov.cn/archive/publications/2015/03/30/content_281475080249035.htm.

${ }^{6}$ For the discussion on the typology of Chinese SOEs see Sheng Hong and Zhao Nong, China's State-Owned Enterprises: Nature, Performance and Reform (World Scientific, 2013), 35-44.

${ }^{7}$ Xing Zhigang, "Li calls on SOEs to keep 'going global”, China Daily, 21 September 2015, http:// europe.chinadaily.com.cn/business/2015-09/21/content_21931678.htm.
} 
supported by the State: (1) outbound investment in infrastructure that is conducive to the BRI, and connects infrastructure in surrounding regions; (2) outbound investment that drives the export of domestic superior production capacity, high-quality equipment and applicable technology; (3) investment cooperation with overseas high-tech and advanced manufacturing enterprises. ${ }^{8}$ The major Chinese SOEs including China Communications Construction, China State Construction Engineering, PowerChina, Sinomach, China Railway Construction Corporation, China Railway Group, China National Petroleum Corporation, and State Grid have already participated in nearly 1,700 projects along the BRI economic corridors. ${ }^{9}$

Another important economic policy that directed Chinese SOEs towards the acquisition of foreign technologies, know-how, and brands is "Made in China 2025". It aims at the modernization of the Chinese manufacturing sector through the gradual replacement of the foreign technologies with Chinese ones in the domestic market and the increased presence of Chinese high-tech companies on international markets. ${ }^{10}$ In the words of the Chinese President Xi Jinping: "We will move Chinese industries up to the medium-high end of the global value chain, and foster a number of world-class advanced manufacturing clusters". ${ }^{11}$ The above mentioned economic policies have led to an unprecedented increase in FDI flows from China to the EU. According to the report by Mercator Institute for China Studies, in 2016 alone the Chinese FDI in the EU saw a 77\% increase compared to $2015 .^{12}$

\footnotetext{
${ }^{8}$ Guiding Opinions on Further Guiding and Regulating the Directions of Outbound Investment, 4 August 2017, paragraph 3.

9 See Baker McKenzie and Silk Road Associates, "Belt \& Road: Opportunity and risk", October 2017, http://www.bakermckenzie.com/en/insight/publications/2017/10/chinas-belt-road-initiative/, 8.

${ }^{10}$ See e.g. Mercator Institute for China Studies, "Made in China 2025: The making of a high-tech superpower and consequences for the industrial countries", December 2016, https://www.merics. org/fileadmin/user_upload/downloads/MPOC/MPOC_Made_in_China_2025/MPOC_No.2_ MadeinChina_2025.pdf.

${ }^{11} \mathrm{Xi}$ Jinping, "Secure a decisive victory in building a moderately prosperous society in all respects and strive for the great success of socialism with Chinese characteristics for a new era" (delivered at the $19^{\text {th }}$ National Congress of the Communist Party of China, 18 October 2017), http://www.xinhuanet.com/english/download/Xi_Jinping's_report_at_19th_CPC_National_Congress.pdf, 26.

${ }^{12}$ Mercator Institute for China Studies, "Record flows and growing imbalances: Chinese investment in Europe in 2016", January 2017, https://www.merics.org/fileadmin/user_upload/downloads/MPOC/COFDI_2017/MPOC_03_Update_COFDI_Web.pdf.
} 
Due to the size of the Chinese "national champions", the bulk of their acquisitions in the EU has undergone screening by the EU Commission under the EU merger control rules. With the exception of the ChemChina/ Syngenta transaction, ${ }^{13}$ which was subjected to a number of remedies, ${ }^{14}$ other cases involving Chinese SOEs have been cleared unconditionally. These cases have attracted a certain degree of scrutiny by legal scholars ${ }^{15}$ and practitioners ${ }^{16}$ pointing out the challenges posed by these transactions for the application of the EU merger control rules, more specifically the assessment of State control over SOEs for the purpose of identifying the "single economic unit". At the same time, little attention has been accorded to the application of the national merger control rules in the Member States where the notified transactions did not reach the "community dimension" under the EU Merger Regulation, ${ }^{17}$ especially given the fact that national merger rules generally follow the EU standards and use similar legal concepts. ${ }^{18}$

The present paper provides an overview of the merger control enforcement involving the Chinese SOEs at the level of the EU Member States and their national competition authorities (NCAs). It commences with the review of the EU merger rules applicable to the economic concentrations

\footnotetext{
${ }^{13}$ Case No. COMP/M.7962 ChemChina/Syngenta, decision of 5 April 2017.

${ }^{14}$ See European Commission, press release IP/17/882 "Mergers: Commission clears ChemChina acquisition of Syngenta, subject to conditions", 5 April 2017, http://europa.eu/rapid/press-release_ IP-17-882_en.htm.

${ }^{15}$ See e.g. Alan Riley, "Nuking misconceptions: Hinkley Point, Chinese SOEs and EU merger law”, European Competition Law Review 37, no. 8 (2016): 301-324; Odd Stemsrud, “'China Inc.' under Merger Regulation review: the Commission's approach to acquisitions by Chinese public undertakings", European Competition Law Review 32, no. 10 (2011): 481-487; Piet Jan Slot, "The application of the EU merger control rules to State owned enterprises", European Competition Law Review 36, no. 11 (2015): 484-492; Alexandr Svetlicinii, "The acquisitions of the Chinese Stateowned enterprises under the EU merger control regime: Time for reflection?", Revue Lamy de la Concurrence 67 (2017): 30-36.

${ }^{16}$ See e.g. Adrian Emch, "EU merger control complications for Chinese SOE transactions", Kluwer Competition Law Blog, 27 May 2016, http://competitionlawblog.kluwercompetitionlaw. com/2016/05/27/eu-merger-control-complications-for-chinese-soe-transactions/; Fountoukakos Kyriakos and Camille Puech-Baron, "The EU merger regulation and transactions involving states or state-owned enterprises: Applying rules designed for the EU to the People's Republic of China", Concurrences 1 (2012): 44-54.

${ }^{17}$ Council Regulation (EC) No 139/2004 of 20 January 2004 on the control of concentrations between undertakings, OJ L 24.

${ }^{18}$ See Liza Bellulo, Gwenaëlle Nouët, "Merger control in the EU and in the 27 Member States: Towards voluntary procedural and substantial convergence?", Concurrences Review 2 (2011): 55-65.
} 
involving SOEs that were interpreted and applied in the EU Commission's merger control enforcement. The discussion then proceeds to the analysis of the national merger control rules and their application by the NCAs of the EU Member States in cases involving Chinese SOEs. The discussion is concluded with a summary of the challenges presented by the recent wave of acquisitions led by the Chinese SOEs and the articulation of the need for a more consistent approach in merger assessment at both EU and national levels.

\section{EU merger control and the State-owned enterprises}

The EU Merger Regulation and the Commission's Jurisdictional Notice ${ }^{19}$ set the legal framework for application of the EU merger control, which is based on the general principle of non-discrimination between the public and the private sectors. ${ }^{20}$ The determination of whether a merger between two SOEs constitutes economic concentration for the purpose of the EU Merger Regulation is based on the concept of "single economic unit" or "single economic entity", which encompasses all undertakings under the single center of decision-making. Therefore, a merger between two undertakings owned by the same State will constitute concentration under the EU Merger Regulation if the undertakings concerned are part of different economic units having an independent power of decision. ${ }^{21}$

The EU Commission has established the existence of a single decisionmaking center in cases where the controlling entity is able to influence the following decisions of the target undertaking: decisions on the appointment of the management; decisions on the adoption of financial plans; decisions on the adoption of business plans; decisions concerning investments; decisions concerning the choice of technology; and decisions concerning product development. ${ }^{22}$ In the case of SOEs, the Jurisdictional

\footnotetext{
${ }^{19}$ Commission Consolidated Jurisdictional Notice under Council Regulation (EC) No. 139/2004 on the control of concentrations between undertakings (2008/C 95/01), OJ C 95.

${ }^{20}$ EU Merger Regulation, recital 22.

${ }^{21}$ Jurisdictional Notice, paragraph 153. As explained by the EU Commission in Neste/Ivo case, "The companies can be considered to be independent undertakings (...) if they are given the power to implement independently their respective commercial conduct on the market and their commercial policy". Case IV/M.931 Neste/Ivo, decision of 2 June 1998, paragraph 7.

${ }^{22}$ See Morten Broberg, "The concept of control in the Merger Control regulation", European Competition Law Review 25, no. 12 (2004): 741-751, 743. For example, in Rosneft/TNK-BP case the EU Commission established a "single economic unit" including all Russian SOEs in the oil and gas industry taking into account the following factors: (1) the members of the board of directors are appointed and removed by the controlling shareholder, which is the Russian State; (2) the members
} 
Notice clearly distinguishes between the powers exercised by the State as a public authority and its powers as a controlling shareholder exercised over the SOE. ${ }^{23}$ The regulatory powers of the State exercised in the public interest are not regarded as control within the EU Merger Regulation. According to the Jurisdictional Notice, "where a State-owned company is not subject to any coordination with other State-controlled holdings, it should be treated as independent". ${ }^{24}$

The identification of the "single economic unit" in the case of SOEs controlled by the same State is also necessary for the calculation of the relevant turnover in order to ascertain whether the concentration reaches the "Community dimension" and therefore the EU Commission must be notified. The EU Merger Regulation applies the following methodology for the calculation of the relevant turnover of the SOEs: "In the public sector, calculation of the turnover of an undertaking concerned in a concentration needs, therefore, to take account of undertakings making up an economic unit with an independent power of decision, irrespective of the way in which their capital is held or of the rules of administrative supervision applicable to them". ${ }^{25}$

\section{EU Commission's assessment of mergers involving Chinese State-owned enterprises}

The above mentioned methodology for the identification of the "single economic unit" in cases concerning undertakings owned by the same State was tested in several recent cases involving the Chinese SOEs. Bluestar/Elkem merger ${ }^{26}$ was among such cases where the EU Commission

\footnotetext{
of the current board of directors were concurrently members of other Russian SOEs (interlocking directorships); (3) the State-nominated members of the board of directors were required by law to cast their vote in accordance with any directives issued by the Russian Government. Case No. COMP/M.6801 Rosneft/TNK-BP, decision of 8 March 2013, paragraph 7.

${ }^{23}$ Jurisdictional Notice, paragraph 53: "the prerogatives exercised by a State acting as a public authority rather than as a shareholder, in so far as they are limited to the protection of the public interest, do not constitute control within the meaning of the Merger Regulation to the extent that they have neither the aim nor the effect of enabling the State to exercise a decisive influence over the activity of the undertaking". See also Judgment of 12 December 2012, Electrabel v. Commission, T-332/09, EU:T:2012:672, paragraphs 86-126.

${ }^{24}$ Jurisdictional Notice, paragraph 194.

${ }^{25}$ EU Merger Regulation, recital 22. See also Case COMP/M.6812 SFPI/Dexia, decision of 21 February 2013, paragraphs 1-23; Case COMP/M.5508 SoFFin/Hypo Real Estate, decision of 14 May 2009, paragraphs 5, 6, 24, and 25.

${ }^{26}$ Case No. COMP/M.6082 China National Bluestar/Elkem, decision of 31 March 2011.
} 
examined the acquisition of the Norwegian company by China National Bluestar Group, an SOE wholly owned by the Chinese State and controlled by the State-Owned Assets Supervision and Administration Commission of the State Council (SASAC), "probably the most important organization in the world that nobody has ever heard of" ${ }^{27}$ In its press release announcing the clearance of the specified merger the EU Commission emphasised that "the assessment of the links between Chinese State-owned companies in the same sector relied on the same criteria as those applied for assessing mergers involving European State-owned companies". ${ }^{28}$ Nevertheless, the EU Commission's decision does not provide a definite answer as to the ultimate decision-making center of the Chinese SOEs involved in the merger. One of the problems identified by the legal practitioners in the aftermath of the case was the apparent lack of substantive information from the SOEs, SASAC, and the Chinese State that would allow the EU Commission to carry out an in-depth assessment of the likelihood of various foreclosure scenarios and coordination among SOEs. ${ }^{29}$

In DSM/Sinochem case the parties submitted that Sinochem was a separate economic entity with independent power of decision because the applicable legislation prevented SASAC from intervening in the strategic decision-making process of this SOE. ${ }^{30}$ The EU Commission referred to the OECD report ${ }^{31}$ on China's regulatory reform stating that the government can influence the commercial decision-making of the SOEs through a number of channels. Nevertheless, in the absence of representation by the Chinese State and accompanying evidence, the EU Commission was

\footnotetext{
${ }^{27}$ Barry Naughton, "The transformation of the State sector: SASAC, the market economy, and the new national champions", in State Capitalism, Institutional Adaptation, and the Chinese Miracle, ed. Barry Naughton and Kellee S. Tsai (Cambridge, 2015), 46.

${ }^{28}$ EU Commission, press release IP/11/394 "Mergers: Commission clears acquisition of the Norwegian company Elkem by China National Bluestar", 1 April 2011, http://europa.eu/rapid/ press-release_IP-11-394_en.htm.

${ }^{29}$ See Frederic Depoortere, "The EU Commission clears in phase I a merger in the silicon sector examining possible coordination by the Chinese State of market behaviour of Chinese Stateowned companies (China National Bluestar/Elkem)" e-Competitions Bulletin 2011, Art. no. 38917. ${ }^{30}$ Case No. COMP/M.6113 DSM/Sinochem/JV, decision of 19 May 2011. See also Porter Elliott, "The EU Commission clears a joint venture in the pharmaceutical sector, after examining possible coordination between Chinese State-owned companies (DSM / Sinochem)", e-Competitions Bulletin 2011, Art. no. 41113.

${ }^{31}$ OECD, "OECD Reviews of regulatory reform: China 2009: Defining the boundary between the market and the State", 5 May 2009, http://www.oecd.org/publications/oecd-reviews-of-regulatoryreform-china-2009-9789264059429-en.htm.
} 
unable to reach a definite conclusion whether Sinochem enjoys an independent power of decision". ${ }^{32}$ The same approach has been followed by the EU Commission in a number of subsequent merger cases including CNAC/Koor Industries, ${ }^{33}$ PetroChina/Ineos, ${ }^{34}$ CNRC/Pirelli, ${ }^{35}$ Mercurial Sinomart, ${ }^{36}$ and CNCE/KM Group. ${ }^{37}$

A turning point for the assessment of the Chinse SOEs' acquisitions under the EU merger control rules was reached in EDF/CGN/NNB case ${ }^{38}$ involving China General Nuclear Power Corporation, Electricité de France, and NNB Holding Company operating nuclear power plants in the United Kingdom. In its assessment the EU Commission found that SASAC had an influence on the decision-making of CGN and, therefore, the latter cannot be considered an autonomous decision-making center. ${ }^{39}$ Due to the Chinese State's ability to coordinate the conduct of the SOEs in the energy sector and in the nuclear industry in particular, all SOEs in the energy sector controlled by the central SASAC should be viewed as a single economic unit for the purpose of the EU Merger Regulation. ${ }^{40}$ Some authors argued that the EU Commission's decision in this case signaled that the "narrow SOE group" approach is no longer tenable for jurisdictional assessments under the EU merger control. ${ }^{41}$ Others argued that the Commission's approach "is unnecessarily broad and fails to adequately understand the competitive landscape in the energy sector". ${ }^{42}$ At the same time, in relation to the EDF/CGN/NNB case, it remained unclear whether the above conclusions apply to sectors other than energy and whether all SOEs controlled by the central

\footnotetext{
${ }^{32}$ COMP/M.6113, paragraph 16.

${ }^{33}$ Case No. COMP/M.6141 China National Agrochemical Corporation/Koor Industries/ Makhteshim Agan Industries, decision of 3 October 2011.

${ }^{34}$ Case No. COMP/M.6151 PetroChina/Ineos/JV, decision of 13 May 2011.

${ }^{35}$ Case No. COMP/M.7643 CNRC/Pirelli, decision of 1 July 2015.

${ }^{36}$ Case No. COMP/M.6807 Mercuria Energy Asset Management/Sinomart KTS Development/ Vesta Terminals, decision of 7 March 2013.

${ }^{37}$ Case No. COMP/M.7911 CNCE/KM Group, decision of 15 March 2016.

${ }^{38}$ Case No. COMP/M.7850 EDF/CGN/NNB, decision of 10 March 2016.

${ }^{39}$ COMP/M.7850, paragraph 37.

${ }^{40}$ COMP/M.7850, paragraph 49.

${ }^{41}$ See Alan Riley, "Nuking misconceptions: Hinkley Point, Chinese SOEs and EU merger law", European Competition Law Review 37, no. 8, 2016: 301-324, 324.

${ }^{42}$ Angela Huyue Zhang, "The antitrust paradox of China Inc.", New York University Journal of International Law and Politics 50, 2017: 159-226, 198.
} 
SASAC constitute a single economic unit. ${ }^{43}$ The approach followed by the EU Commission in this case did not become a norm and the subsequent ChemChina/Syngenta merger was analysed under the "worst case" scenario without reaching a definite conclusion concerning the autonomy of ChemChina from the central SASAC. ${ }^{44}$

As a result, the EU Commission's application of the non-discriminatory treatment of public undertakings under the EU Merger Regulation in the cases concerning acquisitions by the Chinese SOEs has raised a number of questions, which have been largely left unanswered: (1) would a concentration between Chinese SOEs constitute a concentration or internal reorganization under the EU Merger Regulation?; (2) what is the composition of the "single economic unit" which should be taken into account for the calculation of the relevant turnover when determining the existence of "Community dimension"?; (3) does the State control over SOEs, exercised through SASAC, translate into the influence and coordination of the SOEs' commercial conduct in particular sectors?

The indecisive stance on the above mentioned issues stands in stark contrast to the resolute conclusions reached by the EU Commission in its recent report on market distortions in the Chinese economy, ${ }^{45}$ which stipulates that by having party cells in $90 \%$ of all SOEs, the party committees "can potentially wield significant influence, and allow for the CCP to directly influence the business decisions of individual companies" ${ }^{46}$ The report concludes that the competence of CCP "extends to the level of business decisions of individual enterprises" ${ }^{\text {" } 77}$ and that "the applicable laws

\footnotetext{
${ }^{43}$ See Tanisha A. James and M. Howard Morse, "Regulatory hurdles facing mergers with Chinese State-owned enterprises in the United States and the European Union", China Antitrust Law Journal 1, no. 1 (2017): 1-24.

${ }^{44}$ Case No. COMP/M.7962 ChemChina/Syngenta, decision of 5 April 2017. See the EU Commission press release IP/17/882 "Mergers: Commission clears ChemChina acquisition of Syngenta, subject to conditions", 5 April 2017, http://europa.eu/rapid/press-release_IP-17-882_en.htm.

${ }^{45}$ EU Commission press release "The EU's new trade defence rules and first country report", 20 December 2017, http://europa.eu/rapid/press-release_MEMO-17-5377_en.htm.

${ }^{46}$ Commission Staff Working Document on Significant Distortions in the Economy of the People's Republic of China for the Purposes of Trade Defence Investigations, SWD(2017) 483 final/2, 20 December 2017, 26. The report highlights the existence of the two structures in the corporate governance of the Chinese SOEs: legal governance (as prescribed by company laws) and political governance (as prescribed by the CCP organizational rules). See also Jiangyu Wang, "The political logic of corporate governance in China's State-owned enterprises", Cornell International Law Journal 47, 2014: 631-669.
}

${ }^{47} \mathrm{Ibid}$., 39. 
confer upon the Government significant powers which allow it to effectively control SOEs, be it via dedicated supervision bodies - SASAC and local SASACs, be it by directly participating in the operational decisionmaking of SOEs" ${ }^{48}$ More specifically, in relation to the chemical industry analysed in several merger cases, the EU Commission concluded that the Chinese State "aims at restructuring the chemicals market once again by directly intervening into corporate decision-making and impacting supply and demand, thus distorting the market in various chemical sub-sectors through a plethora of measures". ${ }^{49}$

Nevertheless, without clear guidance from the EU Commission, the NCAs of the Member States have been confronted with the same challenges in merger assessment as many acquisitions of the Chinese SOEs did not reach the "Community dimension" and were notified under the national merger rules. The following sections summarise the study of the national merger control rules and their enforcement in the selected EU Member States and countries aspiring for EU membership.

\section{State-owned enterprises in national merger regulations}

Our study reviewed the national merger control rules in the 28 EU Member States with regard to their application to concentrations involving SOEs. The review of the national regulatory frameworks in this domain allows for the identification of three broader groups. The majority of Member States do not have any specific rules on SOEs in their merger control legislation. A far less numerous group of countries have provided for specific SOE-related rules or guidelines. Finally, the third group of Member States, which overlaps with the first two, enforces sector-specific merger regulations.

For example, Denmark has adopted several SOE-specific provisions related to the calculation of the relevant turnover. ${ }^{50}$ For the calculation of turnover for central authorities, the turnover is replaced by the aggregate gross operational expenditure in the preceding accounting year of the ministerial province concerned and in the central government accounts. ${ }^{51}$ For

\footnotetext{
${ }^{48}$ Ibid., 108.

${ }^{49}$ Ibid., 434.

${ }^{50}$ Executive Order No. 808 of 14 August 2009 on the Calculation of Turnover in the Competition Act, https:/www.en.kfst.dk/media/1366/executive-order-on-the-calculation-of-turnover-in-thecompetition-act.pdf.

${ }^{51}$ Executive Order No. 808, paragraph 9(1).
} 
a municipal or regional authority, the turnover is replaced by the aggregate gross operational and investment expenditure in the preceding accounting year. ${ }^{52}$ For the determination of ownership and control, the Danish Competition and Consumer Authority refers to the EU Commission's Jurisdictional Notice. ${ }^{53}$

In France, the competition authority's merger guidelines refer to recital 22 of the EU Merger Regulation, which confirms the principle of non-discrimination between public and private sector. It further stipulates that the State as such cannot be considered as an undertaking and, therefore, when calculating the turnover of the SOEs, the competition authority will only consider the undertakings that belong to a "single economic unit" with autonomous decision-making power. ${ }^{54}$ As a result, if a target undertaking is acquired by an SOE, the following factors can be considered for the purpose of the turnover calculation: (1) to question whether the target company will have, after the operation, an autonomous power of decision (in the case of a positive response the transaction does not constitute a concentration); (2) if the target company does not constitute a "single economic unit" with autonomous decision-making power, it is necessary to determine what the ultimate "acquiring entity" will be, which together with the target company will constitute a "single economic unit"; (3) to determine which undertaking controlled by this "acquiring entity" should be taken into account when calculating the turnover. ${ }^{55}$ Generally, these provisions follow the layout of the EU Commission's Jurisdictional Notice. ${ }^{56}$ When determining the existence of the autonomous power of decision, Autorité de la concurrence can take into account various factors such as the corporate governance of the respective SOEs, the mode of exercising State control, the presence

\footnotetext{
${ }^{52}$ Executive Order No. 808, paragraph 9(2).

${ }^{53}$ The Competition and Consumer Authority's Guidelines to Executive Order No. 808 of 14 August 2009 on the Calculation of Turnover in the Competition Act, February 2014, 13, https://www. en.kfst.dk/media/3304/feb-2014-guidelines-to-the-executive-order-on-notification-of-mergersand-on-merger-fees.pdf.

${ }^{54}$ Lignes directrices de l'Autorité de la concurrence relatives au contrôle des concentrations, 10 July 2013, paragraph 108.

${ }^{55}$ Lignes directrices de l'Autorité de la concurrence relatives au contrôle des concentrations, 10 July 2013, paragraph 109.

${ }^{56}$ Jurisdictional Notice, paragraphs 153, 194-196. Similarly, in Slovakia, the NCA's guidelines on turnover calculation refer to the Jurisdictional Notice when discussing the calculation of turnover of SOEs. See Guidelines of the Anti-Monopoly Office on Calculation of Turnover (in Slovak), http://www.antimon.gov.sk/data/files/387_usmernenie-protimonopolneho-uradu-slovenskejrepubliky-k-vypoctu-obratu.pdf, paragraph 28.
} 
of interlocking directorships, the rules on the circulation of commercial information among the SOEs concerned, etc. ${ }^{57}$

The Hungarian Competition Act provides that "the undertakings...in majority state or municipal ownership and with autonomous decisionmaking powers in determining their market conduct shall be deemed to be independent of each other" ${ }^{58}$ When defining the rules for the calculation of the turnover, the competition law also refers to the concept of "economic unit", which includes undertakings in State ownership with autonomous decision-making powers in determining their market conduct. ${ }^{59}$

Similarly, the Czech NCA's guidelines on the turnover calculations specify that "the turnover of a state-controlled undertaking does not comprise the turnover of all companies that are directly or indirectly controlled by the state, but only those which form part of the same business entity". ${ }^{60}$ For example, if the State-owned shares are concentrated in holding companies, or they are jointly controlled, or it is clear for other reasons that SOEs form a "business entity with independent power to take decisions", the NCA would consider such undertakings a part of the merging parties for the purpose of turnover calculation. The Czech NCA's guidelines are notable because they explicitly state that mergers and acquisitions involving two or more SOEs controlled by the same State should be considered a concentration "on condition that the merging parties have been in the long term acting in the market as independent economic entities". ${ }^{61}$ In such cases, the concentration can be notified by the controlling State acting through the ministries and other administrative authorities, or by the undertaking with public authority powers. ${ }^{62}$

\footnotetext{
${ }^{57}$ Lignes directrices de l'Autorité de la concurrence relatives au contrôle des concentrations, 10 July 2013), paragraph 110. The reliance on these company law mechanisms when assessing the corporate governance of the Chinese SOEs has been criticised for ignoring other State control mechanisms such as party-led appointments of company executives. See Roman Tomasic, "Company law implementation in the PRC: The rule of law in the shadow of the State", Journal of Corporate Law Studies 15, no. 2, 2015: 285-309.

${ }^{58}$ Act LVII of 1996 on the Prohibition of Unfair and Restrictive Market Practices, Article 15(3).

${ }^{59}$ Act LVII of 1996 on the Prohibition of Unfair and Restrictive Market Practices, Article 27(3).

${ }^{60}$ Notice of the Office for the Protection of Competition on Calculation of Turnover for the Purpose of the Control of Concentrations between Undertakings, https://www.uohs.cz/en/competition/decisions-guidelines-and-other-documents.html, paragraph 42.

${ }^{61}$ Notice of the Office for the Protection of Competition on the Notion of 'Undertakings Concerned' under the Act on Protection of Competition, paragraph 41.

${ }^{62}$ Notice of the Office for the Protection of Competition on the Notion of 'Undertakings Concerned' under the Act on Protection of Competition, paragraph 42.
} 
In Estonia the turnover calculation guidelines adopted by the Minister of Economic Affairs and Communications stipulate that if an undertaking is controlled by the State or a local government, such undertaking shall not be deemed to be related through control to other SOEs. ${ }^{63}$ However, if SOEs are jointly managed by a holding company established for such a purpose or their economic activities are coordinated, the turnovers of such undertakings should be added together for the purpose of establishing the application of the national merger control rules.

In Poland the merger guidelines of the Polish NCA - the Office of Competition and Consumer Protection (Urzad Ochrony Konkurencji $i$ Konsumentów or UOKiK) stipulates that the undertakings directly controlled by the Ministry of Treasury do not form one capital group and therefore are subject to notification and approval by the NCA. When, however, such SOEs create their own capital groups, the concentrations implemented within those groups are exempted from the obligation to notify the intention of concentration. ${ }^{64}$ The capital group is essentially equal to a "single economic entity" and is understood as all undertakings controlled directly or indirectly by one undertaking, including that undertaking. ${ }^{65}$

The above review of the national merger control rules indicates that the EU Member States have accorded relatively little attention in their merger control legislation to the assessment of the concentrations involving SOEs. For the most part, the national merger control rules and NCAs' guidelines do not contain any SOE-specific provisions or merely refer to the EU merger control standards laid down in the EU Merger Regulation and the EU Commission's Jurisdictional Notice. Even without such references, the national merger rules generally follow the concept of a "single economic unit" when appraising transactions involving SOEs in terms of the relevant turnover, autonomy in decision-making and (anti)competitive effects. Thus, with little guidance from the EU Commission and the absence of

\footnotetext{
${ }^{63}$ Guidelines for Calculation of Turnover of Parties to Concentration, passed on 22 December 2010, in force from 1 January 2011, https://www.riigiteataja.ee/en/eli/ee/MKM/reg/522042016004/ consolide, paragraph 19.

${ }^{64}$ Guidelines on the Criteria and Procedure of Notifying the Intention of Concentration to the President of UOKiK (UOKiK, 2010), https://uokik.gov.pl/merger_control.php, 9. Concentrations involving local government units, i.e. commune, poviat and voivodeship of the local government, are also subject to the notification. See also Mateusz Blachucki, Polish Competition Law - Commentary, Case Law and Texts (UOKiK, 2013), 45-53.

${ }^{65}$ Guidelines on the Criteria and Procedure of Notifying the Intention of Concentration to the President of UOKiK, 20.
} 
the detailed national rules and guidelines on the matter, the NCAs were expected to further develop the EU Commission's methodology or to formulate their own approaches to the assessment of the concentrations involving Chinese SOEs. The following section analyses the NCAs' merger control experience in this domain.

\section{National Competition Authorities and mergers involving Chinese State-owned enterprises}

The review of the decisions published by the NCAs of the EU Member States indicates that despite its significance for the substantive assessment and procedural aspects of merger control, the State ownership of the Chinese SOEs is often not considered. For example, in 2013 the Hong Kong-based China Merchants Holdings (International) Co Ltd (China Merchants) sought to acquire $49 \%$ of the share capital and voting rights of the company Terminal Link SAS, which owns 15 container terminals in 8 countries across four major continents and was previously controlled by CMA CGM S.A., a French container transportation and shipping company. The transaction was reviewed by the Commission for the Protection of Competition of Cyprus. Although the Cypriot NCA noted that China Merchants "is considered an important investor and operator of ports in China and one of the largest operators of public ports in China, holding shares in fifteen terminals companies", the NCA's decision describes China Merchants as a mere "public company, listed on the Hong Kong stock exchange". ${ }^{66}$ Although on its official website, the China Merchants Group, the parent company of China Merchants, states that it "is a leading state-owned conglomerate based in Hong Kong, under direct supervision of SASAC of the State Council", ${ }^{67}$ the NCA's decision contains no reference to the State control whatsoever. At the same time, in another merger case, notified in the same year, the Cypriot NCA acknowledged the State ownership of China Shipping Terminal Development (Hong Kong) Co Ltd, which was a Hong Kong-based subsidiary of China Shipping (Group) Co, another SOE controlled by the central SASAC. ${ }^{68}$

In Slovakia, the Anti-Monopoly Office assessed a concentration involving Zhengzhou Coal Mining Machinery Group, a listed SOE with

\footnotetext{
${ }^{66}$ Commission for the Protection of Competition (Cyprus), Decision No. 16/2013 of 4 March 2013.

${ }^{67} \mathrm{http} / / /$ wwwen.cmhk.com/main/a/2016/a26/a30448_30530.shtml.

${ }^{68}$ Commission for the Protection of Competition (Cyprus), Decision No. 66/2013 of 21 October 2013.
} 
substantial shareholding controlled by the regional SASAC of Henan province. Although State ownership was acknowledged, no further consideration of this fact was included in the decision. ${ }^{69}$ In 2013, the Danish Competition and Consumer Authority analysed the joint venture of China Shipping Terminal Development (Hong Kong) (CSTD) and Shanghai International Port Group (SIPG) for the operation of a port terminal located in Zeebrugge (Belgium). SIPG was a regional SOE controlled by the Shanghai government, while CSTD was controlled by China Shipping Group, an SOE under the administration of the central SASAC. The merger was cleared under simplified procedure and the decision contains no mention of the State ownership in the acquiring undertakings. ${ }^{70}$ The same transaction has been cleared by the Romanian Competition Council without any assessment of the State control. ${ }^{71}$ Similarly, when the Czech Office for Protection of Competition examined the acquisition of Linde Hydraulics $\mathrm{GmbH}$, a German manufacturer of hydraulic pumps, motors and valves by Weichai Power Co, the NCA considered Shandong Heavy Industry Group as the ultimate controlling entity without addressing the fact that the latter was under control of the regional SASAC of the Shandong province. ${ }^{72}$ The Bulgarian NCA cleared the acquisition of the Serbian steel manufacturer Zelezara Smederevo d.o.o. by He Steel Group Co Ltd, a Chinese SOE controlled by the regional SASAC of the Hebei province without any assessment of the State control. ${ }^{73}$

The merger control practice of the Italian competition authority L'Autorità Garante della Concorrenza e del Mercato (AGCM) demonstrates a far more detailed consideration of the State ownership in the domestic companies rather than in foreign ones, such as those involving Chinese SOEs. For example, in 2012 the AGCM issued a conditional clearance decision in a merger involving two Italian SOEs under control of the Ministry of Economy and Finance (MEF): Cassa Depositi e Prestiti (CDP)

\footnotetext{
${ }^{69}$ Anti-Monopoly Office (Slovakia), Decision No. 725/2017/OK-2017/FK/3/1/019 of 16 June 2017.

${ }^{70}$ Press release BITE-13/10659-20 of 16 October 2013, https://www.kfst.dk/afgoerelser-ruling/konkurrenceomraadet/afgoerelser/2013/20131016-godkendelse-paa-baggrund-af-enforenklet-sagsbehandling-af-apm-terminals-bv/.

${ }^{71}$ Romanian Competition Council, Decision No. 45 of 2 December 2013.

${ }^{72}$ Office for Protection of Competition (Czech Republic), Decision No. ÚOHS-S647/2012/ KS-22387/2012/840/LBr̆ of 27 November 2012.

${ }^{73}$ Commission for Protection of Competition (Bulgaria), Decision No. 461 of 15 June 2016 in case 210/2016.
} 
and Snam, a subsidiary of the incumbent energy giant Eni. ${ }^{74}$ Following the approach articulated in the EU Commission's Jurisdictional Notice, the AGCM concluded that the merging parties' pre-merger constituted two different economic entities with independent decisional powers. While MEF was exercising direct influence on the major corporate decisions of CDP by holding a 70\% stake in its capital, Snam was controlled only indirectly by being a subsidiary of Eni where MEF exercised its voting rights only to pursue public interest objectives. Concerned with the existence of structural links in the form of minority shareholdings, which could facilitate collusion, the AGCM has ordered a number of remedies to address anti-competitive concerns. ${ }^{75}$

When assessing one of the largest Chinese investments in Europe in 2011, the acquisition of Hungarian BorsodChem by Wanhua Industrial Group, the world's leading producer of isocyanate, the AGCM merely noted that the acquiring party is controlled by the People's Republic of China. ${ }^{76}$ In 2012, the Italian NCA examined an acquisition of control over Ferretti S.p.A. by Weichai Holding Group Hong Kong Investment Co. ${ }^{77}$ The relevant product market covered design, construction and marketing of large luxury boats. The acquiring undertaking was part of Weichai Holding Group Co., a Hong Kong-based holding, wholly owned by Shadong Heavy Industry Group. The latter is an SOE under the supervision of the regional SASAC of Shandong province. In its competitive assessment of the notified concentration the AGCM considered the operations of other undertakings under control of the Shandong SASAC. In the case ${ }^{78}$ concerning the acquisition of Ingram Micro Inc. by Tianjin Tianhai Investment Company, the AGCM did not consider the fact that the acquirer's major shareholder is HNA Group, a large Chinese conglomerate active within a number of markets worldwide. ${ }^{79}$

\footnotetext{
${ }^{74}$ AGCM, Decision No. 23824 of 8 August 2012 in case C11695.

${ }^{75}$ See Michele Giannino, "The Italian Competition Authority exerts its jurisdiction on a concentration between two firms owned by the State and conditionally clears it" (CDP/Snam), e-Competitions Bulletin August 2012, Art. no. 49218.

${ }^{76}$ AGCM, Decision No. 21893 of 9 December 2010 in case C10820.

${ }^{77}$ AGCM, Decision No. 23379 of 6 March 2012 in case C11502.

${ }^{78}$ AGCM, Decision No. 26152 of 4 August 2016 in case C12064.

${ }^{79}$ See e.g. Mike Gee, "What do we know about Tianjin Tianhai, the company buying Ingram Micro?", 18 February 2016, https:/www.arnnet.com.au/article/594196/what-do-we-know-abouttianjin-tianhai-company-buying-ingram-micro/. When the same transaction was notified in Slovakia, the Anti-Monopoly Office acknowledged the HNA Group's shareholding in its clearance decision. See Decision No. 2016/FK/3/1/040 of 5 August 2016. The same transaction was cleared
} 
The Hungarian NCA (Gazdasági Versenyhivatal) also followed the approach formulated in the Jurisdictional Notice in relation to the economic independence of SOEs. In 2012, it examined an acquisition involving two Hungarian SOEs controlled by the Minister for National Development. ${ }^{80}$ One of the undertakings was controlled through a limited company owned by the Hungarian State, which is bound by the decisions of the Minister, who is also empowered to adopt and amend its bylaws and appoint the members of the board. Another SOE was a financial institution, which is also controlled by the Minister. However, its bylaws expressly stipulated that the Minister was not entitled to make decisions concerning the business plan or other decisions that are within the competence of the board..$^{81}$ The Hungarian NCA concluded that the two SOEs were controlled by distinct entities and, therefore, their merger constituted an economic concentration for the purposes of the Competition Act.

The situation would be no different if one would survey merger control practices of other European jurisdictions. For example, the Macedonian Commission for Protection of Competition has screened the acquisition of the Serbian steel manufacturing conglomerate Zelezara Smederevo d.o.o. by Hesteel Group, a Chinese SOE, controlled by the SASAC of the Hebei province. ${ }^{82}$ The NCA's decision contains no mention of State ownership in the acquiring undertaking. When the same company acquired control over Luxembourg-based Duferco International Trading Holding, involved in the distribution of steel products, the Macedonian NCA did not acknowledge the State ownership either. ${ }^{83}$ Finally, when examining the CNAC/ Syngenta merger, the Macedonian NCA only considered the immediate parent company of CNAC - ChemChina, without acknowledging that ChemChina is an SOE under the control of the central SASAC. ${ }^{84}$ When calculating the turnover of the parties, the NCA included the turnover of

by the Spanish NCA. The respective press release does not contain any discussion on the acknowledged State ownership of the acquiring party. See Decision C/0858/17 ZMJ/CRCI/NEGOCIO SG of 29 June 2017, https://www.cnmc.es/sites/default/files/1787767_1.pdf.

${ }^{80}$ Hungarian Competition Authority, decision in case Vj-23/2012 of 22 March 2012.

${ }^{81}$ See Zsuzsanna Németh, "The Hungarian Competition Office clears the acquisition of the prospective owner and operator of the gas interconnector between Slovakia and Hungary by two state owned companies (Magyar Villamos Müvek / MFB Invest Befektetési és Vagyonkezelö / Magyar Gáz Tranzit)", e-Competitions Bulletin 2012, Art. no. 49212.

${ }^{82}$ Commission for Protection of Competition (Macedonia), Decision No. 08-30 of 24 June 2016.

${ }^{83}$ Commission for Protection of Competition (Macedonia), Decision No. 08-25 of 2 April 2015.

${ }^{84}$ Commission for Protection of Competition (Macedonia), Decision No. 08-39 of 5 August 2016. 
ChemChina without considering the question of whether the turnover of other Chinese SOEs in the same sector should be included.

In Serbia, the Commission for Protection of Competition assessed the acquisition of Pirelli by CNAC. In its assessment, the NCA noted that CNAC's parent company, ChemChina, is an SOE. Despite the fact that the notifying party submitted voluminous data concerning the corporate governance of ChemChina, the Serbian NCA considered that such information was irrelevant to the competitive assessment of the notified concentration. ${ }^{85}$ When ChemChina notified its acquisition of German equipment manufacturer Kraus Maffei Group GmbH, the Serbian NCA acknowledged the State ownership and control exercised by the central SASAC, but did not consider this issue in the competitive assessment of the merger. ${ }^{86}$ The screening of the CNAC/Syngenta merger in Serbia also did not address the issues related to State ownership and control over CNAC and ChemChina. ${ }^{87}$ Finally, Hesteel's acquisition of Serbian steel manufacturer Zelezara Smederevo d.o.o., which represented a politically significant foreign investment for that country, was cleared through a simplified procedure by the Serbian NCA the day after the approval of the CNAC/Syngenta transaction by the EU Commission. The competition authority did not attribute any significance to the fact that Hesteel Group is a Chinese SOE, controlled by the SASAC of the Hebei province. ${ }^{88}$

The above review of the merger control practice of the NCAs in the EU Member States and other European jurisdictions demonstrates that the issues of State ownership and control receive even less attention than in the cases examined by the EU Commission. In the majority of the national merger decisions, the NCAs have barely acknowledged the State ownership of the SOEs and have provided no justification when defining the scope of the "single economic unit", which was sometimes limited to the group of companies controlled by the regional SASACs or to the SOE parent of the merging parties. While many of the NCAs have previous experience in assessing the mergers of domestic SOEs, their merger decisions

\footnotetext{
${ }^{85}$ Commission for Protection of Competition (Serbia), Decision No. 6/0-02-385/2015-7 of 12 June 2015.

${ }^{86}$ Commission for Protection of Competition (Serbia), Decision No. 6/0-02-120/2016-6 of 12 February 2016.

${ }^{87}$ Commission for Protection of Competition (Serbia), Decision No. 6/0-02-202/2016-13 of 23 May 2016.

${ }^{88}$ Commission for Protection of Competition (Serbia), Decision No. 6/0-02-372/2016-10 of 24 May 2016.
} 
concerning Chinese SOEs displays limited understanding of China's SOE governance rules and institutions.

\section{Concluding remarks}

The following issues remain largely unresolved both in the EU and national merger control practice in relation to the concentrations involving Chinese SOEs: (1) determination of whether mergers between Chinese SOEs should be notified as concentrations; (2) calculation of the relevant turnover for the purpose of establishing the $\mathrm{EU}$ or national merger control jurisdiction; (3) substantive assessment of the notified concentration's likely impact on competition. The first issue has not been considered by either the EU Commission or the NCAs. The second question has mainly been left unanswered since the annual turnover of a single Chinese SOE was sufficient to establish the existence of the "Community dimension", while at the national level the NCAs have considered the turnover of the SOEs controlled by the regional SASACs on a case-by-case basis. The third issue has been addressed by the EU Commission using a "worst case" scenario approach, while at the national level the substantive assessment is largely absent from the published clearance decisions. As has been noted by antitrust scholars, the determination of the "single economic unit" for the Chinese SOEs will have significant impact not only on future merger cases, but also on the enforcement of the EU competition rules (Articles 101 and 102 TFEU) against the potential anti-competitive conduct of these companies. ${ }^{89}$

The continuous application of the "worst case" scenario approach by the EU Commission has provided little guidance to the NCAs as to how to address the issues of State ownership and State control of Chinese SOEs in their domestic merger control practice. As the review of the national merger control rules and guidelines demonstrates, few Member States have explicitly addressed the assessment of SOE-related concentrations and most frequently the reference is made to the EU Commission's Jurisdictional Notice. When it comes to their practical application, the review of NCAs' decisions regarding the clearance of mergers involving Chinese SOEs demonstrates that for the most part the competition authorities pay little regard to the issue of State control and often disregard

\footnotetext{
${ }^{89}$ See Angela Huyue Zhang, "The single-entity theory: An antitrust time bomb for Chinese Stateowned enterprises?", Journal of Competition Law \& Economics 8, no. 4 (2012): 805-830.
} 
it altogether. Unfortunately, the divergence in procedural rules governing national merger control mechanisms leads to the situation when certain NCAs are not required to substantiate the results of their assessment in case of merger clearances. As a result, it is often impossible to comprehend whether and to what extent a particular NCA has taken into account the issue of State control and how it has affected the results of the merger assessment.

The apparent discontent between the EU Commission and the NCAs in terms of their assessment of the Chinese SOEs' acquisitions under merger control rules could potentially lead to the more frequent use of other forms of foreign investment screening, such as a national security review or sector-specific merger control provisions. The EU Commission has already made a decisive step in that direction by submitting a proposal for a regulation, establishing a framework for the screening of foreign direct investments into the European Union, ${ }^{90}$ which has been acclaimed by Germany, France and Italy "as an important step towards a level playing field in Europe". ${ }^{91}$ This move is likely to reinvigorate the existing FDI screening mechanisms $s^{92}$ and lead to the establishment of new ones, which would shift the attention from the competitive assessment of the SOE-related concentrations to the consideration of other public policy objectives.

\footnotetext{
${ }^{90}$ EU Commission, Proposal for a Regulation of the European Parliament and of the Council establishing a framework for screening of foreign direct investments into the European Union, COM (2017) 487 final, https://ec.europa.eu/transparency/regdoc/rep/1/2017/EN/COM-2017-487F1-EN-MAIN-PART-1.PDF. See also Erica Wiking Hager and Carolina Dacko, "EU FDI screening - legal considerations", Mannheimer Swartling, June 2017, https://www.mannheimerswartling.se/ globalassets/publikationer/msa_nyhetsbrev_eu_fdi_mechanism_a4_final.pdf.

${ }^{91}$ Joint press release by Germany, France Italy "EU proposal on investment vetting is an important step towards level playing field in Europe and better protection in case of corporate acquisitions", 13 September 2017, https://www.bmwi.de/Redaktion/EN/Pressemitteilungen/2017/20170913-euvorschlag-zu-investitionspruefungen-wichtiger-schritt-fuer-faire-wettbewerbsbedingungen-ineuropa-und-besseren-schutz-bei-firmenuebernahmen.html.

${ }^{92}$ Currently, the following Member States have screening mechanisms in place: Austria, Denmark, Germany, Finland, France, Latvia, Lithuania, Italy, Poland, Portugal, Spain, and the United Kingdom. For an overview of the national FDI screening mechanisms see Gisela Grieger, "Foreign direct investment screening: A debate in light of China-EU FDI flows", European Parliamentary Research Service, May 2017, http://www.europarl.europa.eu/RegData/etudes/BRIE/2017/603941/ EPRS_BRI(2017)603941_EN.pdf.
} 


\section{Bibliography}

Baker McKenzie and Silk Road Associates. "Belt \& Road: Opportunity and risk".

October 2017. http://www.bakermckenzie.com/en/insight/publications/2017/10/ chinas-belt-road-initiative/.

Bellulo, Liza and Gwenaëlle Nouët. "Merger control in the EU and in the $27 \mathrm{Member}$ States: Towards voluntary procedural and substantial convergence?". Concurrences Review 2 (2011): 55-65.

Broberg, Morten. “The concept of control in the Merger Control regulation”. European Competition Law Review 25, no. 12 (2004): 741-751.

Depoortere, Frederic. "The EU Commission clears in phase I a merger in the silicon sector examining possible coordination by the Chinese State of market behaviour of Chinese State-owned companies (China National Bluestar/Elkem)". e-Competitions Bulletin 2011, Art. no. 38917.

Elliott, Porter. "The EU Commission clears a joint venture in the pharmaceutical sector, after examining possible coordination between Chinese State-owned companies (DSM / Sinochem)". e-Competitions Bulletin 2011, Art. no. 41113.

Emch, Adrian. "EU merger control complications for Chinese SOE transactions". Kluwer Competition Law Blog, 27 May 2016. http://competitionlawblog.kluwercompetitionlaw.com/2016/05/27/eu-merger-control-complications-for-chinese-soe-transactions/.

Fountoukakos, Kyriakos and Camille Puech-Baron. "The EU merger regulation and transactions involving States or State-owned enterprises: Applying rules designed for the EU to the People's Republic of China”. Concurrences 1 (2012): 44-54.

Giannino, Michele. "The Italian Competition Authority exerts its jurisdiction on a concentration between two firms owned by the State and conditionally clears it (CDP/Snam)". e-Competitions Bulletin 2012, Art. no. 49218.

Hague Centre for Strategic Studies. "A road to riches or a road to ruin? The geo-economic implications of China's new silk road”. 15 August 2017. https:/hcss.nl/sites/ default/files/files/reports/Geoeconomics_Behind_OBOR_FINAL\%20\%283\%29.pdf.

Hong, Sheng and Zhao Nong. China's State-owned enterprises: Nature, performance and reform. World Scientific, 2013.

James, Tanisha A. and M. Howard Morse. "Regulatory hurdles facing mergers with Chinese State-owned enterprises in the United States and the European Union". China Antitrust Law Journal 1, no. 1 (2017): 1-24.

Mercator Institute for China Studies. "Made in China 2025: The making of a high-tech superpower and consequences for the industrial countries". December 2016. https:// www.merics.org/fileadmin/user_upload/downloads/MPOC/MPOC_Made_in_ China_2025/MPOC_No.2_MadeinChina_2025.pdf. 
Mercator Institute for China Studies. "Record flows and growing imbalances: Chinese investment in Europe in 2016". January 2017. https://www.merics.org/fileadmin/user_ upload/downloads/MPOC/COFDI_2017/MPOC_03_Update_COFDI_Web.pdf.

Naughton, Barry. "The transformation of the State sector: SASAC, the market economy, and the new national champions". In State Capitalism, Institutional Adaptation, and the Chinese Miracle, edited by Barry Naughton and Kellee S. Tsai, 46-71. Cambridge, 2015.

Németh, Zsuzsanna. “The Hungarian Competition Office clears the acquisition of the prospective owner and operator of the gas interconnector between Slovakia and Hungary by two State owned companies (Magyar Villamos Müvek / MFB Invest Befektetési és Vagyonkezelö / Magyar Gáz Tranzit)”. e-Competitions Bulletin 2012, Art. no. 49212.

Riley, Alan. "Nuking misconceptions: Hinkley Point, Chinese SOEs and EU merger law”. European Competition Law Review 37, no. 8 (2016): 301-324.

Slot, Piet Jan. "The application of the EU merger control rules to State owned enterprises". European Competition Law Review 36, no. 11 (2015): 484-492.

Stemsrud, Odd. “'China Inc.' under merger regulation review: The Commission's approach to acquisitions by Chinese public undertakings". European Competition Law Review 32, no. 10 (2011): 481-487.

Svetlicinii, Alexandr. "The acquisitions of the Chinese State-owned enterprises under the EU merger control regime: Time for reflection?". Revue Lamy de la Concurrence 67 (2017): 30-36.

Tomasic, Roman. "Company law implementation in the PRC: The rule of law in the shadow of the State". Journal of Corporate Law Studies 15, no. 2 (2015): 285-309.

Wang, Jiangyu. "The political logic of corporate governance in China's State-owned enterprises". Cornell International Law Journal 47 (2014): 631-669.

Zhang, Angela Huyue. "The antitrust paradox of China Inc.”. New York University Journal of International Law and Politics 50 (2017): 159-226.

Zhang, Angela Huyue. "The single-entity theory: An antitrust time bomb for Chinese State-owned enterprises?". Journal of Competition Law \& Economics 8, no. 4 (2012): 805-830.

Zukus, Jason. "Globalization with Chinese characteristics: A new international standard?”. The Diplomat. 9 May 2017. https://thediplomat.com/2017/05/globalization-with-chinese-characteristics-a-new-international-standard/. 